\title{
Social and Political Thought in the Russian Religious Renaissance
}

\section{PAul Ladouceur ${ }^{*}$}

Before the Russian revolution of 1917 and subsequently in exile, the leading figures of the Russian religious renaissance were deeply engaged in social and political questions. Vladimir Soloviev, Sergius Bulgakov and Nicolas Berdyaev in particular presented Christian philosophies and theologies as alternatives to secular philosophies which captivated the Russian intelligentsia in late imperial Russia. Their thinking was consistent with evangelical precepts and the social thinking and actions of the early Fathers of the Church, even if not always couched in explicitly Christian terms. Major Christian theological and spiritual principles inspiring their theologies include the equality of all human beings, the evangelical imperative of love of neighbour as a reflection of love of God, the uniqueness of the human person, and freedom. Social and political thinking during the Russian religious renaissance provided a solid, if inadequately recognized, basis for the development of later Orthodox social and political theology.

Keywords: Russian religious renaissance, social theology, political theology, Vladimir Soloviev, Sergius Bulgakov, Nicolas Berdyaev, Mother Maria Skobtsova

Contrasting attitudes towards social and political issues are often said to be reflected in the principal Orthodox theological streams of the twentieth century, the Russian religious renaissance and neopatristic theology, and to have been conditioned by personal, social and political circumstances of the leading Orthodox thinkers associated with each stream. Fr. Alexander Schmemann (1921-1983), in a review of Russian theology up to the early 1970s, writes that "research for a living and 'applied' Orthodoxy was from the beginning one of the mainsprings of the more free 'religious philosophy."' He notes that the former members of the Russian revolutionary intelligentsia who returned to the Orthodox Church both before and after the revolution

\footnotetext{
* Paul Ladouceur, Adjunct Professor at the Orthodox School of Theology at Trinity College University of Toronto, and Professeur associé, Faculté de théologie et de sciences religieuses, Université Laval, Québec. Address: Dr Paul Ladouceur, 3432 -14 $4^{\text {th }}$ Avenue, Rawdon QC, Canada. J0K 1S0, E-mail: 123thabor@gmail.com.

1 Alexander Schmemann, "Russian Theology 1920-1972: An Introductory Survey", in: St Vladimir's Theological Quarterly 16 (4/1972), p. 188.
} 
"kept the radical zeal of their former world." Schmemann cites a number of authors associated with the religious renaissance who wrote on social issues, but the sole representative of the neopatristic approach that he cites is Paul Evdokimov (1901-1970), with his works on woman and marriage. ${ }^{2}$

The fundamental issue in social and political theology is to define the relationship among God, the individual person and the collectivity or the society. Seeking to reconcile these in a coherent vision, the Russian Christian thinkers of the late nineteenth and early twentieth centuries were caught on the horns of a dilemma. Following on their Slavophile predecessors, they wished to define a Christian path for Russian social and political development without embracing either the unacceptable secularism and individualism that they perceived in Western liberalism, or the determinism, atheism and anti-religious aspects of Marxist philosophy, despite their attraction to the desirable goals of socialism.

In the mid-nineteenth century Alexander Bukharev (Archimandrite Theodore) (1829-1871) sketched the contours of Orthodox engagement with modernity, especially in his book On Orthodoxy in Relation to the Modern World (1860), a collection of fifteen essays and a short conclusion dealing with a wide range of topics. ${ }^{3}$ Bukharev uses the subject of each essay to articulate his main thesis that Orthodoxy must engage with the modern world. Each essay becomes a platform from which Bukharev can hammer home his central theme:

We should defend all aspects of humanity as the property of Christ... The repression, constraint and especially the repudiation of anything truly human, is an infringement of Christ's grace. [...] Orthodoxy should shine like a sun in all civil life, in the whole circuit of our sciences, arts and official relations. ${ }^{4}$

But Bukharev did not elaborate a comprehensive Orthodox theology of modernity, including social and political theology. This task became increasingly urgent at the end of the nineteenth century, as the Russian imperial

2 A. Schmemann, "Russian Theology 1920-1972", p. 189. See Paul Evdokimov, Woman and the Salvation of the World, Crestwood, NY, St. Vladimir's Seminary Press 2011; idem, The Sacrament of Love, Crestwood, NY, St. Vladimir's Seminary Press 2011.

3 Alexander Bukharev, O Pravoslavii v otnochenu k sovremennosti [On Orthodoxy in relation to the modern world] Saint Petersbourg, Sinodal'naia tipografiia 1860; $2^{\mathrm{e}}$ ed., 1906. Very little of Bukharev's writings is available in translation. Paul Valliere presents a summary and commentary on the 16 essays of On Orthodoxy in Relation to the Modern World in Modern Russian Theology: Bukharev, Soloviev, Bulgakov. Orthodox Theology in a New Key, Grand Rapids MI, Eerdmans 2000, p. 35-72, and Elisabeth Behr-Sigel comments on it in Alexandre Boukarev - Un théologien de l'Église orthodoxe russe en dialogue avec le monde modern, Paris, Beauchesne 1977, p. 64-72.

4 A. Bukharev, O Pravoslavii, p. 20, 316. Cited in Vasili V. Zenkovsky, A History of Russian Philosophy, I, London-New York, Routledge 2003, p. 317. 
regime was increasingly challenged as an archaic aristocratic and autocratic social and political system unable to respond to the new challenges posed by capitalism, industrialization and the import of new ideas and philosophies emanating in Western Europe.

In late imperial Russia, the intelligentsia, constituted a broad intellectual, social and political movement characterized by several key features. ${ }^{5}$ These included notably a deep concern for Russia's social problems, especially the situation of the poor and the oppressed, a critical and even hostile attitude towards the government and the aristocracy which maintained fundamentally oppressive and unjust political and social structures, and a certain self-consciousness of its own existence. For many intelligenty, this configuration of ideas coalesced around one central goal: the abolition of the monarchy and with it the entire aristocratic and autocratic socio-political structure of Russian society, and its replacement with a modern social, economic and political system inspired by western models. Another characteristic of much of the intelligentsia was opposition to the Church, at least to the Church's role in society because of its close association with the detested imperial regime. Most of the intelligentsia was non-religious or anti-religious, but there emerged a small but brilliant Christian intelligentsia, composed of philosophers, theologians and also writers such as the novelists Fyodor Dostoyevsky (1821-1881) and Leon Tolstoy (1828-1910).

Several prominent leaders of the Christian intelligentsia, among them notably Nicolas Berdyaev and Sergius Bulgakov, returned to Christianity from Marxism, retaining a high level of social conscience, which they now redefined in the light of Christianity. The acceptable economic and social objectives of Marxism which attracted leading members of the Russian religious renaissance include notions of the fundamental equality of all members of society, the responsibility of society for all its members, the redistribution of wealth, the right to equitable remuneration for work and universal social programmes in education, health and other domains. The unacceptable aspects of Marxism are of course its inherent materialism and atheism, its view of humans solely as social and economic entities, a dialectical view of history interpreted as class struggle, and, especially evident in Lenin's Bolshevism, the use of violence as a means to achieve social and political objectives, the

\footnotetext{
5 There are numerous studies of the intelligentsia. For attempts to define the intelligentsia, see notably Nicolas Zernov, The Russian Religious Renaissance of the Twentieth Century, New York, Harper \& Row 1963, p. 1-34; Christopher Read, Religion, Revolution and the Russian Intelligentsia, 1900-1912: The Vekhi Debate and Its Intellectual Background, London, Macmillan 1979, p. 1-6; Martin Malia, "What Is the Intelligentsia?" and Richard Pipes, "The Historical Evolution of the Russian Intelligentsia", in: Richard Pipes (ed.), The Russian Intelligentsia, New York, Columbia University Press, 1961.
} 
"dictatorship of the proletariat" (which in practice meant the rule of communist leaders), the suppression of opposition and freedom of expression and the seizure of property without compensation.

\section{Vladimir Soloviev}

Although many early leaders of the Russian religious renaissance were imbued with a sensitive social conscience, Vladimir Soloviev (1853-1900) was the principal architect who laid solid foundations for the emergence of modern Orthodox social and political thought. Soloviev's central political idea early in his career is summed up in the expression "free theocracy". For Soloviev, free theocracy was not theocracy in the normal sense of political rule by religious leaders. He referred to this notion of theocracy as "false theocracy," 6 as typified in Roman Catholic and Orthodox clericalism in the Byzantine Empire, Rome and Russia. Soloviev's free theocracy is rather "the actualization of the divine principle in the world" , a principle visible in the first instance in the Church, whose organization is neither aristocratic nor democratic, but "it is, in fact, definitely theocratic, ruled by God." 8 On the level of the state, the sense of the somewhat nebulous concept of free theocracy is that the religious aspirations of the population must be reflected in the goals of the state (hence "theocracy") and must be freely realized, not imposed by state or religious power (hence "free theocracy").

Soloviev's theocracy is an application of the notions of all-unity (vseedinstvo), the fundamental solidarity of all things: "the connecting of all functions and institutions in society to the love of God," in Paul Valliere's words, and of Godmanhood (bogochelovechestvo), the cosmic implications of the Incarnation of the Logos. ${ }^{9}$ Soloviev, like many of his contemporaries and successors in the religious renaissance, struggled to balance personal freedom and the needs of the community, leading to "the ideal of a free community," ${ }^{10}$ a system of governance characterized by autonomy of key spheres of modern societies, such as commerce, law, science and culture. Soloviev places a high value on the

\footnotetext{
6 Vladimir Soloviev, Kritika otvlechennykh nachal [The Critique of Abstract Principles], Soloviev's doctoral thesis, 1880 in Russian, p. 161, cited by P. Valliere in: Modern Russian Theology, p. 131.

7 V. Soloviev, The Spiritual Foundations of Life, GW II, p. 107, cited in Marin Terpstra, “'God's Case on Earth': Notes on Theocracy and the Political Theology of Vladimir Soloviev," in: Wil van den Bercken et al. (eds.), Soloviev, Reconciler and Polemicist, Leuven, Peeters 2000, p. 421.

8 V. Soloviev, God, Man and the Church: The Spiritual Foundations of Life, Cambridge, James Clarke 1974, p. 153.

9 P. Valliere, Modern Russian Theology, p. 130.

10 V. Soloviev, Kritika, p. 166, cited in: P. Valliere, Modern Russian Theology, p. 127.
} 
value, dignity and freedom of the human person, and thus he favours the separation of Church and state, reflected in the expression "a free Church in a free state," 11 as well as the protection of human rights, including freedom of belief.

Later in his all too-short career, Soloviev shied away from the easilymisunderstood expression free theocracy, but he developed in more detail the idea of social and economic justice, especially in his late work The Justification of the Good (1897). Here he seeks a Christian middle way between capitalist exploitation of the poor and radical socialist egalitarianism by advocating the necessity of providing the minimum material means for a "dignified existence." Soloviev sees the religious and the political spheres as working in harmony, each with distinct goals and motivation, with the church envisioned as "collectively-organized piety" and the state as "collectively-organized pity" (Soloviev's emphasis) - "pity" in the sense of mercifulness, empathy or "loving-kindness." 12 The state is responsible for the elevation of the principle of mercifulness "from the level of an impotent and strictly limited feeling and gives it reality, its broad application and development," permitting the provision of "pity, i.e., provide help and protection, to tens and hundreds of millions of people, instead of to tens and at most hundreds of individuals"13 - "hundreds of individuals" being the practical limits of personal action.

Soloviev defines "pity" as the correct relation among humans; thus pity is linked with moral truth and justice:

The true essence of pity is not a simple identification of oneself with another, but the recognition of the other's own (proper) significance... This idea of pity, taken as universal and as independent of the subjective mental states connected with it (i.e., taken logically and not psychologically), is connected with moral truth and justice. It is true that other creatures are similar to me, and it is right that I treat them as I do myself.

\footnotetext{
${ }_{11}$ Ibidem, p. 132.

12 V. Soloviev, Justification of the Good: An Essay on Moral Philosophy (1897), translated and edited by Thomas Nemeth, Cham, Springer International Publishing 2015, p. 399. The unfortunate English word "pity" fails to convey the full strength of the idea of unconditional love, agape, which lies behind Soloviev's notion of "pity." The Russian word translated as "pity" is zhalost, but the Russian sense is much more than pity in normal English usage: "Zhalost' differs from pity... in the presence of 'loving' feelings toward the unfortunate target person... and in its absence of potentially invidious comparisons with other people... Unlike pity, zhalost' is, potentially, a feeling that can embrace all living creatures, just as love can”. Anna Wierzbicka, Semantics, Culture, and Cognition, New York, Oxford University Press 1992, p. 168. Wierzbicka points out that Soloviev calls zhalost" the root of an ethical attitude towards... other human beings and towards living creatures in general." In a theological perspective, zhalost' is close to the Slavonic milost', the Greek eleos and the Latin misericordia, for which there are no equivalent English words, although the expression "loving-kindness" is often used in translations.
}

13 V. Soloviev, Justification of the Good, p. 399. 
Pity in this sense is thus close to the Christian ideal of altruistic love, agape, and is therefore truth, whereas egoism is untruth:

Altruism as corresponding to moral truth, or to what is, and egoism as presupposing an untruth, or what is not, since the individual self does not in fact have the exclusive and central significance that it ascribes to itself in egoism. Although the extension of personal egoism to the family, the nation, the state and religion expresses the historical achievements of morality, it does not eliminate the fundamental lie of egoism, which is refuted by the unconditional truth of the altruistic principle. ${ }^{14}$

In his social and political thought, Soloviev thus articulates a profoundly Christian philosophical and theological foundation for modern social legislation, which incorporates the idea of collective responsibility for the provision of the means for "minimum human dignity" for all members of the polity, and indeed in a broad sense for all humanity - the theological foundation for international development assistance. For the Christian, the state and social and economic structures create opportunities for the evangelical love of neighbour, so vividly portrayed in Christ's parable of the Good Samaritan (Lk. 10.25-37).

Soloviev remained realistic about the acceptability of his political theology. In a letter to his French friend the philosopher of religion Eugène Tavernier (1854-1928), Soloviev wrote:

If it is clear that the truth will only be definitively accepted by a small and likely persecuted minority, we must once and for all abandon the idea of the power and external grandeur of theocracy as the direct and immediate goal of Christian politics. Its goal is justice, and glory is only a consequence which will come on its own. ${ }^{15}$

Despite the occasional complexity and ambiguity of his ideas, Soloviev's notions of free theocracy, autonomous social spheres, and collective responsibility for all members of a society remained powerful attractions for his contemporaries and successors in the Russian religious renaissance. Soloviev was long identified with political conservatism, but recent scholarship stresses his liberal views, ${ }^{16}$ even though he departs from classical Western European lib-

\footnotetext{
14 Ibidem, xiv. Both citations are from Soloviev's "Table of Contents." For the full development of these points, see Chapter 3: "Pity and Altruism," VII, p. 63-65.

15 V. Soloviev, La Sophia et les autres écrits français, Lausanne, L'Âge d'Homme 1978, p. 338.

16 See: Andrzej Walicki, "Vladimir Soloviev: Religious Philosophy and the Emergence of the 'New Liberalism'”, Chapter III, in: idem, Legal Philosophies of Russian Liberalism, Oxford, Clarendon Press 1987; Greg Gaut "A Practical Unity: Vladimir Solov'ev and Russian Liberalism”, in: Canadian Slavonic Papers 42 (3/2000), p. 295.
} 
eralism in deriving his political and social principles from a Christian vision of relations between God and humanity, characterized above all by mutual love, rather than a typically humanist foundation originating in the Renaissance and the Enlightenment. Aristotle Papanikolaou refers to Soloviev's thought as "Christian liberalism or "Christian secularism," a modern expression of divine-human communion as the key to sound Orthodox political theology. ${ }^{17}$ Soloviev's political theology can also be considered an extension of the notions of all-unity and Godmanhood, more problematic ideas which largely disappeared from Orthodox thought after World War II, as we saw in Chapters 9 and 10. But his political theology does not rely directly on these difficult notions.

\section{Fr. Sergius Bulgakov}

Several former Marxists who retained their social commitment after their conversion or return to Orthodoxy set out to justify acceptable social goals for Christian action by grounding Christian social thought more explicitly than Soloviev in the New Testament and the social thought of the early Fathers. The task was not easy, because social and political thought in Russia at the beginning of the twentieth century had coalesced around two poles, the autocracy and authoritarianism of the decaying imperial regime, with the Russian Orthodox Church as its ally, and radical atheistic humanism, embodied in political movements bent on the violent overthrow of the monarchy, the aristocracy and the capitalist regime, and their replacement by an imposed socialist society. Socially concerned Christians were thus caught between autocratic imperialism and atheistic humanism. There was no Christian middle ground for them to occupy, but it had to be created, under the inspiration of the social and political thought of Soloviev and reflected in such popular writings as the novels of Feodor Dostoyevsky.

In a key text published in September 1905 at the height of the aborted Revolution, Fr. Sergius Bulgakov (1871-1944) proposes to resolve the dilemma by defining a Christian approach to social and political issues. "An Urgent Task" is an attempt to recoup what can be salvaged from humanist and Marxist socialism in a Christian perspective, a passionate plea for Christian politics and specifically Christian socialism. ${ }^{18}$ Bulgakov wrote this article after he had broken with Marxism and embraced Christianity philo-

\footnotetext{
17 Aristotle Papanikolaou, The Mystical as Political: Democracy and Non-Radical Orthodoxy, Notre Dame IN, University of Notre Dame Press 2012, p. 34-35.

18 "An Urgent Task" was first published in Voprosy zhizni [Problems of Life], an intelligentsia journal edited by Nicolas Berdyaev. Translation in: Bernice Glatzer Rosenthal, Martha Bohachevsky-Chomiak (eds.), A Revolution of the Spirit: Crisis of Value in Russia, 1890-1924, New York, Fordham University Press 1990.
} 
sophically, but before his active return to the Church, which occurred a few years later, around 1908 . He was still very much distraught by the unholy alliance of the Russian Orthodox Church with the imperial regime and the article contains bitter denunciations of Church bureaucracy and the subservience of the Church to the government. ${ }^{19}$ In places Bulgakov's language is quasi-Marxist, coming very close to endorsing the Marxist notion of class struggle. ${ }^{20}$

Bulgakov's theological argument for Christian politics and Christian socialism reposes on three pillars: first, the Incarnation of Christ and history as "the process of God-Man, wherein a united mankind, 'the body of Christ,' is assembled and organized"; secondly, Christ's precept of love of neighbour, which "must be extended not only to inner feelings but to outer or social and political relations as well"; and finally the "absolute dignity of the human person, who bears God's image."21 Bulgakov is in the line of Alexander Bukharev and tserkovnost" when he writes: "Christianity extends its sphere of interests and influence over all realms of life; it determines all human life, according to its own idea, from the first cry to the last." Against the argument that personal charity satisfies Christian social obligations, Bulgakov contends that personal morality must extend to "social morality, that is, politics." It is in this theological context that Bulgakov endorses typically humanist ideals such as "the emancipation of all humanity, universal freedom, for which there can be no distinction among nationalities, religions or denominations," "the human person's natural and sacred rights to freedom of speech, freedom of conscience, freedom of association," separation of Church and State, and "complex social techniques of social legislation, workers' organizations, strikes and the cooperative movement," and even such measures as increasing direct taxes and introducing progressive income tax.

Bulgakov's views here are thus similar to Soloviev's, as expressed in The Justification of the Good, but Bulgakov more explicitly endorses typically liberal social and political objectives. His article is both a theological treatise and a manifesto for Christian politics and ends with a call for the establishment of a Union of Christian Politics, devoted to "the cultivation of Christian community." ${ }^{22}$ Bulgakov was one of the founders of the Union of

19 For examples, see: S. Bulgakov, "An Urgent Task”, p. 139-140, 144.

20 Referring to the existence of "struggling classes," Bulgakov writes that "One cannot stand above this social struggle; rather, one must intervene in it actively and consciously." S. Bulgakov, "An Urgent Task", p. 147.

21 This and subsequent quotations in this paragraph from S. Bulgakov, "An Urgent Task", p. $142-150$.

22 Ibidem, p. 158. For a study of the development of Bulgakov's social and political thought in this period, see especially Catherine Evtuhov, The Cross \& the Sickle: Sergei Bulgakov and 
Liberation in 1902, which became the Constitutional Democratic ("Kadet") Party. He did in fact found a Union of Christian Politics and was elected to the short-lived Second Duma (February to June 1907) as an independent Christian socialist. But the experience of the fractious and ineffective Duma left him disillusioned and he never returned to active politics. ${ }^{23}$

Beginning with The Unfading Light (1917), Sergius Bulgakov's first properly theological work, and for the rest of his life, the great theologian was primarily concerned with typically dogmatic theological questions, especially the elaboration and defence of his doctrines of Godmanhood and sophiology. Although disheartened by the perverse nature of Russia's socialist revolution, of which he was himself a victim (loss of his teaching posts and exile), he did not abandon completely his earlier preoccupation with social, economic and political issues, which are reflected in a number of publications in the early and mid-1930s. In 1932 Bulgakov published an important essay on "The Soul of Socialism" in the periodical Novyi grad (The New City). ${ }^{24}$ Closely associated with Novyi grad were Ilya Fondaminski (1880-1942) and Mother Maria Skobtsov (St Maria of Paris) (1891-1945) and it is likely that they influenced Bulgakov's return to social themes in the early 1930s - Bulgakov was Mother Mariass spiritual father and he supported her wish to become a nun and her social, intellectual and cultural undertakings.

The spirit of Bulgakov's "The Soul of Socialism" is markedly different from "An Urgent Task," as three decades of turmoil and conflict left its marks on the author. Gone is the enthusiasm for Christian socialism, its place taken by a certain pessimism about socialism, arising from the bitter experience of the Russian Revolution. Socialism is now seen almost exclusively as communism, a "materialist economism," inexorably connected with fatalism and revolution: "Socialism has a soul of its own - a soul that is admittedly wholly pagan - and a spirit which has so far been decidedly hostile to God." 25 This is a far cry from Christian notions of a religious interpretation of economics: "The Christian ideal of the Kingdom of God is realized historically in a whole series of alternating historical tasks: at the present

the Fate of Russian Religious Philosophy, Ithaca NY, Cornell University Press 1997, particularly Ch. 7, "Christian Socialism".

23 See: Rowan Williams (ed.), Sergii Bulgakov: Towards a Russian Political Economy, Edinburgh, T\&T Clark 1999, p. 55-61; C. Evtuhov, The Cross \& the Sickle, p. 115-126.

24 Sergius Bulgakov, “The Soul of Socialism”, in: R. Williams (ed.), Sergii Bulgakov: Towards a Russian Political Economy. Novyi grad, edited notably by the historian Georges Fedotov and published by YMCA-Press between 1932 and 1939, was more socially and politically oriented than Put'(The Way), the leading philosophical-theological periodical of the Russian religious intelligentsia in the inter-war period, edited by Nicolas Berdyaev.

25 S. Bulgakov, "The Soul of Socialism", p. 239. 
time, one of these is the attainment of social justice along with personal liberty." ${ }^{26}$ But Bulgakov fails to see his way to a Christian socialism, or even to support for a secular, humanist welfare or socialist movement purged of communist, atheist and anti-religious baggage.

In the autumn of 1934 Bulgakov visited Canada and the United States, where he delivered a lecture at the Seabury-Western Theological Seminary (Evanston, IL) on "Social Teaching in Modern Russian Orthodox Theology." 27 In his analysis of the history of social concern in Orthodoxy, Bulgakov stresses, like others of his time, that the concern for personal salvation and asceticism resulted in a flight from the world on the part of both individuals and the Church and a corresponding neglect of social issues, with the result that "the vacuum created by the absence of social leadership on the part of Christianity was filled in by a new paganism or by atheistic humanism." ${ }^{28}$ Bulgakov ties social theology to ecclesiology, arguing that "the task of the Church includes not only ways of personal salvation but of the transfiguration of the world" and he posits Christian humanism as an answer to the question of "false, atheistic humanism" put to the Church, the "opposite of the godless humanism of modern times": "All these creative efforts must be made in the name of Jesus Christ; being inspired by the Holy Ghost, Pentecost is continued." ${ }^{29}$ Love is the foundation of Christian social and political engagement: "Social life is to be organized according to the postulates of Christian love, so also the whole of political life." 30 The weaknesses of Bulgakov's analysis lies in his failure to account adequately for social teachings and undertakings in the early Church and in the history of monasticism, and in casting humanism into two "opposite streams of thought," atheistic humanism, identified almost entirely with "materialistic socialism, especially communism," and Christian humanism. ${ }^{31}$ Despite a more positive tone than in "The Soul of Socialism" two years earlier, Bulgakov does not admit the possibility of non-religious liberal humanism free of militant communist atheism, with which Christian humanism could collaborate in the edification of a modern state reflecting Christian values.

Bulgakov takes a more conciliatory position in his book The Orthodox Church (1935), intended for a non-Orthodox audience, which contains chapters on "Orthodoxy and the State" and "Orthodoxy and Economic

$26 \quad$ Ibidem, p. 248.

27 Sergius Bulgakov, Social Teaching in Modern Russian Orthodox Theology: The Twentieth Annual Hale Memorial Sermon, Evanston IL, Seabury-Western Theological Seminary 1934. Reprinted in R. Williams (ed.), Sergii Bulgakov.

28 Ibidem, p. 10.

29 Ibidem, p. 15, 16.

$30 \quad$ Ibidem, p. 17.

31 Ibidem, p. 20. 
Life." "Orthodoxy should not oppose socialism," writes Bulgakov, "if the latter recognizes individual liberty; quite the contrary, for socialism is the realization in social life of the commandment of love."32

Taken as a whole, Bulgakov's late social and political thought is very much in the line of Alexander Bukharev - the full engagement of Christianity with society:

We must seek for a state of things in which the Church may penetrate as with inward power the whole of human life. The separation of the Church from life must be overcome, and all sides of the natural existence of men - certainly excluding sin - are to be included in the grace-abounding life of the Church. ${ }^{33}$

\section{Nicolas Berdyaev and Mother Maria (Skobtsova)}

There was a certain tension concerning differing approaches to social and political issues between the older generation of Russian theologians of the religious renaissance and the younger generation who had not participated in pre-revolutionary debates about the future of Russia and was more attuned to neopatristic theology. In his typical brash manner, Nicolas Berdyaev (1874-1948) takes Georges Florovsky (1893-1979) to task for the failure to recognize tyranny and the struggle against oppression in Florovsky's The Ways of Russian Theology:

[Florovsky] does not understand the theme of moral indignation against the wronging and oppression of man. He considers it appropriate to deprecate Vladimir Soloviev for seeking social justice and the realization of Christian justice in society... Fr. G. Florovsky ignores the anguish of the Russian soul in the face of the terrible evil of serfdom, the debasement of man by the autocracy, and the impact that this had on all Russian thought... Fr. G. Florovsky evidently considers moral feelings and heightened consciousness as utopianism and he struggles not only against romanticism, but also against utopianism. ${ }^{34}$

Berdyaev's reference here to "utopianism" is the search for a more just social order which was, as we have seen, the major preoccupation of the pre-revolutionary Russian intelligentsia. Berdyaev goes on to speculate that Byzantine theology itself may provide an explanation for the apparent neglect of social justice in Florovsky's book:

32 Idem, The Orthodox Church (1935), Yonkers NY, St Vladimir's Seminary Press 1988, p. 173.

33 S. Bulgakov, Social Teaching, p. 17.

34 Nicolas Berdyaev, "Ortodoksiya i chelovechnost" (Ortodoxia and Humanness), in: Put' 53 (1937), p. 53-65. Citations from an online English translation by Fr. Steven Janos: <www.berdyaev.com/Berdyaev/berd_lib/1937_424.html>, viewed on 05.04.2015. 
This might perhaps be explained by the failure of Byzantine Orthodoxy to be authentically involved with man. When man is seen exclusively as a sinful being in need of salvation, the abasement of man and affronts against his dignity are ignored.

Berdyaev has of course inadequately characterized "Byzantine Orthodoxy" as concerned "exclusively" with salvation, ignoring the social concerns reflected in the Gospels and the epistles and the social initiatives of St Basil the Great and St John Chrysostom and other early Fathers. But he does nonetheless have a point: a strong focus on more narrowly "theological" or "metaphysical" issues has led to a relative neglect of questions of social justice in Orthodox thought. This critique is often associated with a related criticism, that the strong emphasis on personal salvation and ascetic practices frequently found in Orthodoxy can too easily result in a debasing of material concerns, social and political issues and even the human body. Orthodox monasticism is sometimes criticized for the same reasons..$^{35}$ In his 1905 essay "An Urgent Task," Bulgakov places among the "antisocial forms of Christianity" "that medieval monastic Christianity that denies all earthly tasks and teaches us to look above the God-forsaken sinful earth." ${ }^{36}$ While this critique could apply to both Eastern and Western Christianity, again it overlooks the social undertakings of monasteries in health, education, hospitality and famine relief.

The commitment to social ideals did not remain purely theoretical for a number of Russian intellectuals, both prior to the revolution and in exile. There are several important examples of personal commitment to the improvement of the well-being of the poor. These include two women who engaged in social activities, both of whom were martyred and both now canonized, St Elizabeth (Feodorovna) of Russia (1864-1918) and St Maria of Paris (Mother Maria Skobtsova). They had very different personalities, but were united in one conviction, that love of God must be manifested in love of neighbour, not in an abstract sense, but in actual social commitment. Both founded social undertakings, Elizabeth in pre-revolutionary Russia and Mother Maria in inter-war Paris. Elizabeth Feodorovna established the Mission of Martha and Mary in Moscow, a religious order of women devoted to

35 Fr. Alexander Schmemann was known for his disregard for monasticism. In the entry in his Journal for Janaury 20,1981, he writes: "More and more often it seems to me that revising the monasticism that everybody so ecstatically talks about-or at least trying to revive it-can be done only by liquidating first of all the monastic institution itself, i.e. the whole vaudeville of klobuks, cowls, stylization, etc." The Journals of Father Alexander Schmemann 1973-1983, Crestwood NY, St Vladimir's Seminary Press 2002, p. 284. See the discussion and references in Andrew Louth, Modern Orthodox Thinkers: From the Philokalia to the Present, London, SPCK 2015, p. 208.

36 S. Bulgakov, “An Urgent Task," p. 150. 
social action, like Roman Catholic and Lutheran social religious communities. It was successful but was closed by the Bolsheviks in 1919, after Elizabeth herself had suffered martyrdom in 1918 as a member of the Russian imperial family. ${ }^{37}$

During the revolution, Mother Maria, then Elizabeth Kuzmin-Karavaev, was actively involved both in national politics as a member of the Socialist Revolutionary Party, in competition with Lenin's Bolsheviks, and in local politics, as deputy mayor then mayor of her hometown municipality of Anapa on the Black Sea. In the 1930s she established charitable institutions in Paris. She enjoyed the support not only of Sergius Bulgakov and Metropolitan Evlogy (Georgievsky) (1868-1946), but also the active collaboration in her undertakings of intellectuals such as Nicolas Berdyaev, Fr Lev Gillet ("A Monk of the Eastern Church") (1893-1980), art critic and writer Constantin Motchulski (1892-1948) and writer and publisher Ilya Fondaminski (1880-1942). After Mother Maria's arrest by the Gestapo in 1943 and her deportation and death in a German concentration camp in 1945, her charitable works were not continued by others ceased. ${ }^{38}$

Both Elizabeth of Russia and Maria of Paris have become inspirations for similar undertakings. Elizabeth of Russia's community was revived in Saint Petersburg after the fall of communism in Russia, and inspired a sister community in Minsk, Byelorussia.

Mother Maria's social theology revolved around the idea that a Christian social conscience in the modern world is an imperative necessity flowing from the gospel commandments, love of God and love of neighbour, since one cannot be separated from the other, and a vision of the world as a prolongation of the liturgy:

The "liturgy outside the church" is our sacrificial ministry in the church of the world, adorned with living icons of God, our common ministry, an all-human sacrificial offering of love... In this liturgical communion with people, we partake of a communion with God; we really become one flock and one Shepherd, one body, of which the inalienable head is Christ. ${ }^{39}$

\footnotetext{
37 Grand Duchess Elizabeth (Feodorovna) of Russia, a grand-daughter of Queen Victoria, was a German princess married to Grand Duke Sergei Alexandrovitch (1857-1905), son of Alexander II. She was both aunt to Nicholas II by her own marriage, and his sister-in-law by the marriage of her sister Alexandra to Nicholas. On the Mission of Martha and Mary, see P. Ladouceur, "New Institutions in Modern Orthodox Spirituality", in: St Vladimir's Theological Quarterly 55 (4/2011), p. 447-456.

38 See: P. Ladouceur, "New Institutions," p. 471-474.

39 Mother Maria Skobtsova, "The Mysticism of Human Communion”, in: Mother Maria, Essential Writings, Maryknoll NY, Orbis Books 2003, p. 81.
} 
In her classic essay "The Second Gospel Commandment" (1939), Mother Maria argues from Scripture, the liturgy, the Church Fathers, and even the texts in the Philokalia, for the essential unity of religious life and social commitment, in a holistic caring for the other: "Christian love teaches us to give to our brother not only material but also spiritual gifts." ${ }^{40}$ Mother Maria refers even to the need "to give one's soul for one's neighbours," 41 a human solidarity which reflects both sincere empathy for the plight and sufferings of another and a caring for the psychological and spiritual well-being of all. The final stages of her own life were, of course, an example of such a total commitment and she remains, as she wrote in one of her many poems, a "call" to her fellow Christians rather than merely a "memory." 42

\section{Conclusion}

Much of modern Orthodox thought concerning social and political questions vacillates around three basic orientations: a profound engagement with contemporary social and political issues; a detached and laissez-faire attitude which leaves many observers puzzled, dismayed or even outraged; and a nostalgic wistfulness for a romanticized past typically identified with the Byzantine and Russian Empires, overshadowed by the notion of symphonia, the ideal, never really achieved in practice, of the harmonious governance of a Christian ruler and the Orthodox Church over a Christian people in a Christian state.

A Christian perspective on social and political issues was one of the major themes of the Russian religious renaissance. The leading figures of this movement grappled with the problem of defining a Christian alternative to the immobility of the autocratic and authoritarian Russian state and its supporters in the upper echelons of the Russian Orthodox Church on the one hand, and atheistic and anti-religious philosophies which called for the overthrow of the imperial regime, and the Church with it, and its replacement by a revolutionary regime, on the other hand. In Vladimir Soloviev and his successors, especially Sergius Bulgakov and Nicolas Berdyaev, we find the basis of a social and political theology consistent with evangelical precepts and the social and political thinking and actions of the early Fathers of the Church, especially St John Chrysostom and St Basil the Great. Although the leading philosopher-theologians of the religious renaissance did not always

\footnotetext{
40 Idem, "The Second Gospel Commandment", in: Mother Maria, Essential Writings, p. 54.

41 Ibidem, p. 59.

42 Cited in Hélène Arjakovsky-Klépinine, "La Joie du don," in: Mère Marie Skobtsov, Le Sacrement du frère, Paris, Le Cerf 2001, p. 69. "I do not want to be a memory. For you, I will be a call." See also P. Ladouceur, "The Social and Political Theology of Love in St Maria of Paris," Sobornost (forthcoming 2018).
} 
couch their thinking in explicitly Christian terms, their social and political thought flows from such fundamental theological and spiritual principles as the ontological equality of all human beings, the evangelical imperative of love of neighbour as a reflection of love of God, the uniqueness of the human person, and freedom as an aspect of the divine image in humanity.

The leaders of the religious renaissance in exile after the Russian revolution and the civil war deepened their reflection on these themes. Despite the bitter experiences of the revolution and exile, the most prominent of this group, especially Berdyaev, Bulgakov and Mother Maria Skobtsova, sought to accommodate their thinking to the new personal circumstances in which they found themselves, as a minority in Western states dominated by an ethos of state neutrality in religious matters and growing commitments to large-scale social programmes under state auspices. Orthodox social and political theology is still in its infancy. The important legacy of the social and political thought of the Russian religious renaissance is half-forgotten, but nonetheless offers invaluable insights for Orthodox thinking in the early twenty-first century. 